\title{
Clinical Study of Intra Uterine Fetal Death
}

\section{Dr Najmun Nisa ${ }^{1}$, Dr Sipra Singh ${ }^{2}$, Dr Fauzia Shafi ${ }^{3}$, Dr Gauri Rani ${ }^{4}$ \\ ${ }^{1,3,4}$ PGT $3^{\text {rd }}$ year, Dept. of Obstetrics \& Gynaecology, KMCH \\ ${ }^{4}$ Professor, Dept. Of Obstetrics \& Gynaecology, KMCH}

\section{Introduction}

The death of a foetus is one of the unhappy events in the field of obstetrics. It's distressing when in occurs without warning in a pregnancy that has previously seemed entirely normal. It is thus vital to identify specific probable causes of fetal death to determine the risk of recurrence, prevention or corrective action. For an obstetrician, documentation of primary event or factor which has led to fetal death is of paramount importance. Only when probable etiology is known the illiteracy, poor socioeconomic condition and social status of women and misbelieves are important contributory factors responsible for higher fetal mortality rate.

Newer techniques of diagnosis and a letter understanding of pathophysiology, have led to the determination of cause of death in a greater proportion of fetal deaths than in the past.Others like eclampsia, pre-eclampsia, Rhisoimmunisation, diabetes, post-maturity, are preventable by good antenatal care.

\section{Materials and Method}

The cases of intra-uterine fetal death either with ultrasound reports proving IUD or diagnosed on clinical examination by absence of fetal heart rate and fetal movements were studied. Study consisted of 100 patients taken from Katihar Medical College, Katihar from the period of may 2017 to may 2018.

All cases of IUD with Singleton pregnancies of gestational age> 28 weeks were included in the study.

The age, parity, literacy, socio-economic status was recorded. Detailed obstetric history, present complaints and duration, present pregnancy, past obstetric performance and outcomes (including previous abortions, previous IUFD, were studied. In the present pregnancy, details of antenatal check-ups, medical illness, presence of antepartum haemorrhage, pregnancy induced hypertension, eclampsia, severe anaemia and other significant illness were noted. Those patients who had attended antenatal clinic at least thrice before delivery were considered booked cases.

Clinical examination was done. General condition of the patient was noted. In absent FHS was noted any bleeding from os or prolapsed of cord noted liquor-colour and smell were noted. Complete examination of foetus and placenta were done following delivery.

\section{Results}

The present study consisted of 100 intrauterine fetal deaths during study period. 
In this study, pre-eclampsia constituted for $30 \%$ of all still births. Abruption placenta accounted for $20 \%$; unexplained 10\%; congenital anomalies $10 \%$; cord prolapsed $2 \%$; Transverse lie with hand prolapsed $1 \%$; rupture uterus $2 \%$; Others less than $3 \%$ each.

Of 100 cases, 64 patients (64\%) were in labour, where as labour was induced in $36(36 \%)$ patients. The most common method of induction was with

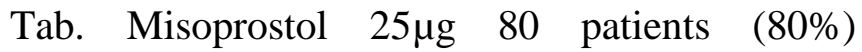
delivered vaginally, 17 patients (17\%)required LSCS and laparotomy was done in 3 patients (3\%)

Table - 01 Causes of intra-uterine fetal death

\begin{tabular}{|l|c|c|c|}
\hline Sl. No. & Causes & Total & $\%$ \\
\hline 1 & Pre-eclampsia & 30 & $30 \%$ \\
\hline 2 & Eclampsia & 10 & $10 \%$ \\
\hline 3 & Abruptio placenta & 20 & $20 \%$ \\
\hline 4 & Unexplained & 10 & $10 \%$ \\
\hline 5 & Congenital anomalies & 10 & $10 \%$ \\
\hline 6 & Placenta praevia & 1 & $1 \%$ \\
\hline 7 & Cord prolapsed & 2 & $2 \%$ \\
\hline 8 & Transverse lie with hand \\
prolapsed & 1 & $1 \%$ \\
\hline 9 & Post-maturity & 2 & $2 \%$ \\
\hline 10 & Rh-isoimmunisation & 2 & $2 \%$ \\
\hline 11 & Infections & 1 & $1 \%$ \\
\hline 12 & Diabetes & 1 & $1 \%$ \\
\hline 13 & Oligohydramnios & 2 & $2 \%$ \\
\hline 14 & $\begin{array}{c}\text { Meconium aspiration } \\
\text { syndrome (intrapartum } \\
\text { asphyxia) }\end{array}$ & 2 & $2 \%$ \\
\hline 15 & Rupture uterus & 2 & $2 \%$ \\
\hline 16 & Prolonged and obstructed & 1 & $1 \%$ \\
\hline 17 & Breech presentation & 1 & $1 \%$ \\
\hline 18 & Anaemia & 2 & $2 \%$ \\
\hline & Total & 100 & $100 \%$ \\
\hline
\end{tabular}

Table - 02 IUDs and antenatal care

\begin{tabular}{|l|c|c|}
\hline Antenatal care & Total & Percentage \\
\hline Booked & 26 & $26 \%$ \\
\hline Unbooked & 74 & $74 \%$ \\
\hline Total & 100 & 100 \\
\hline
\end{tabular}

Table - 03 Insufficient ANC and IUDs

\begin{tabular}{|l|l|c|c|}
\hline $\begin{array}{l}\text { Sl. } \\
\text { No. }\end{array}$ & Causes & $\begin{array}{c}\text { No. Of } \\
\text { cases }\end{array}$ & $\%$ \\
\hline 1 & Abruptio placenta & 15 & $20.27 \%$ \\
\hline 2 & Cord prolapsed & 1 & $1.35 \%$ \\
\hline 3 & Congenital anomalies & 6 & $8.11 \%$ \\
\hline 4 & $\begin{array}{l}\text { Prolonged labour \& } \\
\text { obstructed labour }\end{array}$ & 3 & $4.05 \%$ \\
\hline 5 & Placenta praevia & 2 & $2.70 \%$ \\
\hline
\end{tabular}

\begin{tabular}{|l|c|c|c|}
\hline 6 & Pre-eclampsia & 20 & $27.03 \%$ \\
\hline 7 & Eclampsia & 8 & $10.81 \%$ \\
\hline 8 & Anaemia & 3 & $4.05 \%$ \\
\hline 9 & Rupture uterus & 3 & $4.05 \%$ \\
\hline 10 & Unexplained & 10 & $13.51 \%$ \\
\hline 11 & $\begin{array}{c}\text { Transverse lie with hand } \\
\text { prolapsed }\end{array}$ & 1 & $1.35 \%$ \\
\hline 12 & Breech presentation & 1 & $1.35 \%$ \\
\hline 13 & Post-maturity & 1 & $1.35 \%$ \\
\hline \multicolumn{2}{|c|}{ Total } & 74 & $100 \%$ \\
\hline
\end{tabular}

Table - 04 Mode of delivery

\begin{tabular}{|l|c|c|}
\hline Mode of delivery & Total & Percentage \\
\hline Vaginal & 80 & $80 \%$ \\
\hline LSCS & 17 & $17 \%$ \\
\hline Laparotomy for rupture uterus & 3 & $3 \%$ \\
\hline Total & 100 & $100 \%$ \\
\hline
\end{tabular}

\section{Discussion}

Poor socioeconomic status, poor nutrition leads to anaemia and malnutrition which is a major contributor for perinatal mortality. Illiteracy, lack of awareness of adequate antenatal care and unsupervised deliveries also contribute to higher stillbirth rate.

The IUFD rates were higher in unbooked cases as compared to booked cases.

$\mathrm{PIH}$ and eclampsia constituted major cause of IUFD. This emphasizes the importance of proper antenatal care with screening and prevention of preeclampsia with low dose aspirin. Also early detection and appropriate management of pre eclampsia reduces perinatal mortality and morbidity.

\section{Conclusion}

Fetal loss is a sensitive indicator of maternal care during antenatal period. This study showed that majority of IUDs was preventable. Early detection of pre-eclampsia by regular ANCs and its treatment can reduce its complications including IUD and abruption placenta in few cases thereby further reducing the stillbirth rate.

\section{References}

1. Misra PK, Thakur S, Kumar A, Tandon S. Perinatal mortality in rural India with special references to high risk pregnancies. J Trop Pediatr 1993; 39:41-4. 
2. Kumari R, Mengi V, Kumar D, Maternal risk factors and pregnancy wastage in a rural population of Jammu District. JK Sci 2013;15:82-5.

3. Al Kadari, Hanan $\mathrm{T}$, Hani. Factors contributing to intra uterine fetal death. Arch ObstetGynaecol. 2012;286(5):1109.

4. Patel S, Thaker R, Shah P, Majumdar S. Study of causes and complications of intra uterine fetal death (IUFD). Int J Reprod Contracept Obstet Gynecol 2014;3:931-5.

5. Chitra K, Nitin N, AnuradhaK, Anil S. Intrauterine fetal death: a prospective study. J Obstet Gynaecol India. 2001;51(5):94-7. 